\title{
REMEMBERING SCIENTIFIC WORK OF LATE PROFESSOR JANUSZ KOTLARCZYK, PH.D. SC., ENG., ACTIVE MEMBER OF PAU (POLISH ACADEMY OF ARTS AND SCIENCES) AND PAN (POLISH ACADEMY OF SCIENCES)
}

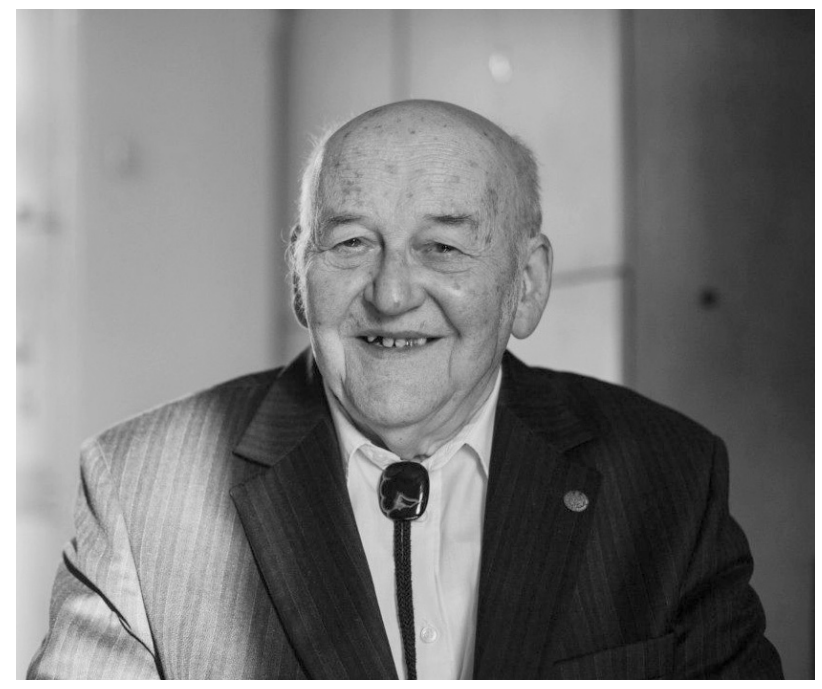

On $1^{\text {st }}$ October 2017 Professor Janusz Kotlarczyk, Ph.D. Sc., Eng., died. He was the founder of the Commission of Geoinformatics at the Division IV of PAU (Polska Akademia Umiejętności - (Polish Academy of Arts and Sciences), Honorary Chairman of this Commission, the founder and long-time member of the Scientific Council of Geoiformatica Polonica, having great achievements in the development, propagation and promotion of theoretical knowledge and various applications of informatics (inter alia: image analysis methods, neural networks, expert systems, data warehouse) in the whole spectrum of the Earth.

Professor Janusz Kotlarczyk (born in 1931) graduated from the Faculty of Geology and Prospecting, AGH University of Science and Technology in Krakow in 1955. In 1963 he received his Ph.D. in geolo- gy. He completed his habilitation (Ph.D. Sc.) in 1977. He obtained the title of Professor in 1980 and became Full Professor in 1991. In the same year, he was elected the correspondent member of PAN (Polska Akademia Nauk - Polish Academy of Sciences), and two years later - the correspondent member of PAU.

Professor Janusz Kotlarczyk connected his scientific career with AGH-UST; at his faculty he was the director of the Institute of Regional Geology and Coal (19691974) and the head of the Department of General and Mathematical Geology (1969-1999). He made a school of mathematical geology and geoinformatics. He organized over 20 national and international geo-mathematic symposia. He was awarded many times, inter alia: decorated with the Knight's Cross of the Order of Polonia Restituta, Gold Cross of Merit, "Meritorious for the Polish Geology" medal, Officer's Cross of the Order of Polonia Restituta, Medal of the National Education Commission.

The scope of scientific research of Professor Kotlarczyk was very broad and included: stratigraphy, sedimentology, palaeontology, regional and general geology, deposit issues and the application of statistical methods in geology. Together with botanist J. Piórecki, he made the project of the Landscape Park of the Przemyśl Foothill and a new national park within it.

In the area of stratigraphy, the pioneer studies on isochronism of Jasło limestones deserve particular attention. Professor J. Kotlarczyk made a new stratigraphic division of Cretaceous formations of the Skole Unint. Together with Professor A. Jerzmanowska he 
carried out the studies on fossil fish in Menilite shales, which led to the discovery of deep sea fish with the preserved light organs (the whole paper was published in USA). The effect of these studies was also a spectacular discovery of the biocoenosis of the Sargassum Sea type (the area of relative stagnation) in Menilite sediments.

Another important area of the Professor's research were the studies over the silicon formations, in particular diatomite, which opened a new chapter in the geologic of Oligocene formations in the Carpathian flysch. The Professor discovered a diatomite deposit in the Carpatia and indicated its application as an environmentally friendly (sozotechnical) raw material (participation in 3 patents), which lead to their exploitation.

In the area of methodological and theoretical studies, it is particularly important to mention the bases of the strategy of the search of ores, as well as oil and gas with statistical methods and informatics.
Numerous publications by Professor J. Kotlarczyk have been widely quoted in Polish and foreign literature.

International co-operation of the Professor included two areas: co-operation with Carpathian geologists from Lviv, Bucharest, Bratislava and Brno (in the framework of Geological Carpathian-Balkan Association) and fruitful scientific contacts with geo-mathematicians from St. Petersburg, Moscow, Berlin, Freiberg and Prague. He was a member of many Polish and international associations. Even after his retirement, in 2004, he still actively participated in the works of the PAU Commission of Geoinformatics. He was also reviewing articles. He knew St. John Paul II - a friend of his whole family. He was a humanist and erudite, interested in the world and people. It is difficult to accept the loss of someone, who still could be with us. But his numerous works and good memories of his numerous students and co-workers remained.

Co-workers

Jadwiga Maciaszek

Tadeusz Chrobak 